Abstracta Iranica Iranica

Revue bibliographique pour le domaine irano-aryen

Volume 22 | 2001

Comptes rendus des publications de 1999

\title{
« Islam in Tajikistan: Tradition and Modernity ». Religion, State \& Society, 26/1 (1998), pp. 39-50.
}

\section{Reinhard Eisener}

\section{Q OpenEdition}

1 Journals

Édition électronique

URL : http://journals.openedition.org/abstractairanica/36777

DOI : 10.4000/abstractairanica.36777

ISSN : 1961-960X

\section{Éditeur :}

CNRS (UMR 7528 Mondes iraniens et indiens), Éditions de l'IFRI

\section{Édition imprimée}

Date de publication : 15 mai 2001

ISSN : 0240-8910

\section{Référence électronique}

Reinhard Eisener, " «Islam in Tajikistan: Tradition and Modernity ». Religion, State \& Society,

26/1 (1998), pp. 39-50. », Abstracta Iranica [En ligne], Volume 22 | 2001, document 344, mis en ligne le 17 février 2010, consulté le 13 octobre 2020. URL : http://journals.openedition.org/abstractairanica/ 36777 ; DOI : https://doi.org/10.4000/abstractairanica.36777

Ce document a été généré automatiquement le 13 octobre 2020.

Tous droits réservés 
« Islam in Tajikistan: Tradition and Modernity ». Religion, State \& Society, 26/1 (1998), pp. 39-50.

Reinhard Eisener 
1 This brief survey, remarkably enough, does not follow current trends to track down 'the Islamic threat', instead of that drawing almost an opposite picture of a continuous local Islamic tradition, which hardly would allow radical Islamic movements to get a firm footing in Tajikistan. This look at continuities reveals noteworthy phenomena. Not least because of the influence of 'Naqšbandîya Islam' mediating between dogmatic prescriptions and pre-Islamic beliefs and customs, the author detects that « in Soviet Tajikistan the 'struggle against the survival of religion' did not inflict serious damage on the Islamic tradition» (p.42). Religious practice and instruction continued on an unofficial level, «the activity of Central Asian atheists in many ways recalled that of puritanical foreign Muslims", and "'learned' Islam was preserved by the local intelligentsia, particularly those in the humanities». The revival and official readmission of Islam in the late 1980s resulted basically in two tendencies: «moderate traditionalist (chiefly apolitical) and radical neotraditionalist (chiefly politicised)». The latter variant « was first and foremost the response of a traditional society to the rapid process of industrialisation which was devastating» (p. $44 \mathrm{ff}$.). The next step, "the radicalisation of the Islamic opposition on the eve of civil war took place mainly as a result of the clumsy actions of the authorities in Dushanbe ». Despite this development and subsequent armed struggle (also supported by foreign radical Islamist organisations), Nijazi can point to numerous, more or less convincing evidences which illustrate that the political views held within Tajik Islamic opposition circles were and are in their vast majority far from representing anything what could be called 'fundamentalist' in a usual sense (particularly for the question of 'political Islam' see also a further developed version of this article by the same author: "Vozroždenie islama v Tadžikistane: tradicija i politika " [The Renewal of Islam in Tajikistan: Tradition and Politics], CAiK, 5 [6] (1999), pp. 153-164.

\section{INDEX}

Thèmes : 7. Islam

\section{AUTEURS}

REINHARD EISENER

Berlin (Allemagne) 